ISSN 0258-7122

Bangladesh J. Agril. Res. 38(1): 165-174, March 2013

\title{
PROFITABILITY OF ROSE CULTIVATION IN SOME SELECTED AREAS OF JESSORE DISTRICT
}

\author{
M.A. Haque ${ }^{1}$, M. A. Monayem Miah², S. $\operatorname{Hossain}^{3}$ AND M. Alam $^{4}$
}

\begin{abstract}
Rose cultivation is now a profitable enterprise to the farmers, but the socioeconomic data and information of this flower are very scarce in Bangladesh. So, the present study was conducted to identify agronomic practices, analyze relative profitability, and input-output relationship during December 2010. A total of 100 rose growing farmers were randomly selected for this study. The results indicated that $100 \%$ farmers cultivated Lincoln variety of rose. The costs of rose cultivation were Tk. 3,87,569 and Tk. 2,75,214 per hectare on full cost and variable cost basis, respectively. The major share of full cost was incurred for human labour (30\%), followed by land use (23\%), fertilizer (17\%), and irrigation (12\%). The yield of rose was 5,40,107 flowers per hectare. The net return from rose cultivation was Tk. 23,31,196 per hectare. The benefit cost ratios were 2.29 and 1.63 on variable cost and full cost basis, respectively. The highest profit was obtained from rose cultivation compared to its competitive crops like potato+jute, lentil+til and mustard+mungbean for rose. Human labor, land preparation cost, seedling, urea, TSP, MoP and irrigation had positive effect on the yield of rose. Lack of technical knowledge, non-availability of HYV seedling, and infestation of insects and diseases were major problems found in rose cultivation. Government should take necessary steps to overcome these problems.
\end{abstract}

Keywords: Rose, profitability, gross margin, net return, BCR.

\section{Introduction}

Commercial floriculture in Bangladesh is a new dimension in farming culture. Evidences from all civilizations reveal that mankind has historical interest in gardening and culturing flowers to satisfy aesthetic need. But, in the present world, flower becomes important not only for its aesthetic social values, but also for its economic contribution (Aditya, 1992; Dadlani, 2003). People usually use flowers in all their ceremonies like wedding, birthday and marriage day greetings, religious offerings and sometimes in social, political and historical occasions. The universal usage has created a real trend of producing flower on a commercial basis to meet increasing demand in the market. The area under rose cultivation was 111 ha producing about 2423 tonnes with an average yield of $21.92 \mathrm{t} / \mathrm{ha}$. The annual growth rate of area, production and yield of marigold for

${ }^{1}$ Principal Scientific Officer, ${ }^{2}$ Senior Scientific Officer, ${ }^{3}$ Chief Scientific Officer, Agricultural Economics Division, and ${ }^{4}$ Scientific Officer, Oil Seed Research Centre, Bangladesh Agricultural Research Institute (BARI), Gazipur, Bangladesh. 
the period from $2005-2006$ to $2009-2010$ were $6.30 \%, 7.89 \%$ and $1.59 \%$, respectively (Table 1 ).

Table 1. Mean, coefficient of variation and growth rates of rose, 2005- 06 /2009-10.

\begin{tabular}{lcccc}
\hline \multicolumn{1}{c}{ Year } & Area (ha) & Prod (mt) & Yield (t/ha) \\
\hline $2005-2006$ & 91 & 1658 & 18.25 \\
$2006-2007$ & 83 & 2328 & 27.96 \\
$2007-2008$ & 91 & 2353 & 25.95 \\
$2008-2009$ & 106 & 2400 & 22.71 \\
$2009-2010$ & 111 & 2423 & 21.92 \\
\hline Mean & 96 & 2232 & 23.36 \\
CV (\%) & 11.9 & 14.5 & 16.1 \\
Growth rate (\%) & 6.30 & 7.89 & 1.59 \\
\hline
\end{tabular}

Source: BBS, 2010

Considering the market value, some farmers in association with some entrepreneurs have started cultivation of gladiolus, tuberose, marigold, rose, gerbera and orchid flowers. But the socio-economic data and information regarding rose cultivation is very much scarce in Bangladesh. Nevertheless, rose cultivating farmers are depriving from higher production and fair prices due to various farm level constraints that need to be explored.

With this view in mind, the present study was undertaken to (i) identify the existing agronomic practices of rose cultivation; (ii) measure the relative profitability of rose with major competing crops; (iii) determine the input-output relationship of rose cultivation; and (iv) find out the socio-economic constraints to its higher production.

\section{Materials and Method}

Sampling technique: A multi-stage sampling technique was followed in this study to select study area and sample farmers. In first stage of sampling, one major rose growing district namely Jessore was selected purposively. In the second stage, Jhikorgacha Upazila was selected for sample survey. In the third stage, a complete list of rose growers was collected from the study area, and finally a total of 100 rose farmers were selected by random sampling technique. The rose farmers / gardens were categories into four: Ist year, $2^{\text {nd }}$ year, $3^{\text {rd }}$ year and $4^{\text {th }}$ year on the basis of the duration of cultivation. In order to compare the benefit of rose cultivation with other existing competing crops, potato + jute, lentil+til and mustard+mungbean for rose were selected. The competitive crops were selected on the basis of same soil and land type of rose cultivation in the study areas. Rice 
is not considered a competitive crop of rose because farmers cultivate rice as scattered in the study area.

Method of data collection: Data for the present study were collected from sample rose farmers through face to face interview method using a pre-tested interview schedule. Field level data were colleted by the researcher with the help of trained enumerators for the period of December, 2010

Analytical techniques: Both fixed cost and variable cost were taken into account in calculating cost of rose cultivation. Land use cost was calculated on the basis of per year existing lease value of land. The profitability of rose cultivation was examined on the basis of gross margin, net return and benefit cost analysis. The collected data were edited, summarized, tabulated and analyzed to fulfill the objectives of the study. Tabular method using descriptive statistics was mostly used in the study. Cobb-Douglas production function model was used to estimate the contribution of factors to rose cultivation. The functional form of the Cobb-Douglas production function model is given below:

$$
\mathrm{Y}=\mathrm{AX}_{1}{ }^{\mathrm{b} 1} \mathrm{X}_{2}{ }^{\mathrm{b} 2}
$$

The production function was converted to logarithmic form so that it could be solved by least square method i.e.

$$
\ln Y=\operatorname{lna}+b_{1} \ln X_{1}+b_{2} \ln X_{2}+\ldots \ldots \ldots \ldots \ldots \ldots \ldots . \ldots b_{n} \ln X_{n}+U_{i}
$$

The empirical production function model was the following:

$$
\begin{aligned}
\ln Y= & a+b_{1} \ln X_{1}+b_{2} \ln X_{2}+b_{3} \ln X_{3}+b_{4} \ln X_{4}+b_{5} \ln X_{5}+b_{6} \ln X_{6}+b_{7} \ln X_{7} \\
& +b_{8} \ln X_{8}+U_{i}
\end{aligned}
$$

Where, $\mathrm{Y}=$ Yield of rose (No/ha), $\mathrm{X}_{1}=$ Human Labour (Man-day /ha), $\mathrm{X}_{2}=$ Land preparation cost (Tk/ha), $X_{3}=$ Seedling (No./ha), ${ }_{4}=$ Manure $(\mathrm{kg} / \mathrm{ha}), \mathrm{X}_{5}=$ Urea (kg/ha), $X_{6}=$ TSP $(\mathrm{kg} / \mathrm{ha}), \mathrm{X}_{7}=\mathrm{MoP}(\mathrm{kg} / \mathrm{ha}), \mathrm{X}_{8}=$ Irrigation cost $(\mathrm{Tk} / \mathrm{ha})$, $A=$ Intercept, $b_{1}, b_{2}$------------- $b_{8}=$ Coefficients of the respective variables to be estimated and $\mathrm{U}_{\mathrm{i}}=$ Error term.

\section{Results and Discussion}

\section{Agronomic practices of rose}

It was found that hundred percent farmers used power tiller for land preparation. The average number of ploughs per farm was 6 (Table 2). All the farmers planted seedling/cutting of rose in line. The planting time of rose seedling/cutting started from mid February and continued up to mid March. The average number of weeding, insecticide spraying and irrigation per farm were 18, 16 and 19 respectively. In the study area, $70 \%$ farmers prune their rose garden within mid October to mid November and 30\% farmers pruning within mid February to mid March. In the first year garden, $100 \%$ farmers started harvesting rose flowers 
from the month of April and continued up to next January but in the second, third, and fourth year gardens, $70 \%$ farmers' harvested rose flowers from the month of January and continued up to September and only 30\% farmers started harvesting rose flowers between April and January. It was happened mainly due to variation of pruning period. Hundred percent farmers in the study area cultivated Lincoln variety of rose.

Table 2. Agronomic practices of rose cultivation in the study area.

\begin{tabular}{|c|c|c|c|c|c|}
\hline \multirow{2}{*}{ Items } & \multicolumn{5}{|c|}{ Agronomic practices } \\
\hline & Ist year & $2^{\text {nd }}$ year & 3rd year & $4^{\text {th }}$ year & All \\
\hline Ploughing (no./farm) & 6 & - & - & - & 6 \\
\hline \multicolumn{6}{|l|}{ Planting method (\% of farmers): } \\
\hline Line & 100 & - & - & - & 100 \\
\hline \multicolumn{6}{|l|}{ Planting time: } \\
\hline Mid Feb.-Mid March & 100 & - & - & - & 100 \\
\hline Weeding (no./farm) & 15 & 19 & 21 & 18 & 18 \\
\hline Spraying insecticides (no./farm) & 16 & 17 & 18 & 15 & 16 \\
\hline Irrigation (no./farm) & 18 & 19 & 22 & 17 & 19 \\
\hline \multicolumn{6}{|l|}{ Time of pruning (\% of farmers): } \\
\hline Mid Oct.-Mid Nov. & - & 70 & 70 & 70 & 70 \\
\hline Mid Feb.- Mid March & - & 30 & 30 & 30 & 30 \\
\hline \multicolumn{6}{|l|}{ Harvesting time : } \\
\hline Jan.-Sept. & - & 70 & 70 & 70 & 70 \\
\hline April.-next January & 100 & 30 & 30 & 30 & 30 \\
\hline \multicolumn{6}{|l|}{ Types of rose (\% of farmers): } \\
\hline Lincoln & 100 & 100 & 100 & 100 & 100 \\
\hline
\end{tabular}

\section{Input use pattern}

The number of human labour used for growing rose was 726 man-days per hectare. The cost of land preparation was Tk.1880. The average number of seedlings/cutting was 7304 per hectare. The respondent farmers used $1546 \mathrm{~kg}$ of manures per hectare. Rose farmers also used chemical fertilizers like urea, TSP, MoP, Zipsum, Zinc sulphate, and Boron at the rate of $1710 \mathrm{~kg}, 1194 \mathrm{~kg}, 592 \mathrm{~kg}$, $453 \mathrm{~kg}, 33 \mathrm{~kg}$, and $2 \mathrm{~kg}$ per hectare, respectively. The use of urea, TSP, and MoP were found higher than the recommended doses (Urea $1302 \mathrm{~kg} / \mathrm{ha}$, TSP 1000 kg/ha, and MoP 400kg/ha) (Table-3). 
Table 3. Input use pattern of rose cultivation in the study area.

\begin{tabular}{l|c|c|c|c|c}
\hline \multirow{2}{*}{ Items } & \multicolumn{5}{c}{ Input use pattern } \\
\cline { 2 - 6 } & Ist year & $2^{\text {nd }}$ year & 3rd year & $4^{\text {th }}$ year & All \\
\hline $\begin{array}{l}\text { Human labour (man- } \\
\text { days/ha) }\end{array}$ & 704 & 766 & 688 & 748 & 726 \\
$\quad$ Family & 306 & 320 & 301 & 319 & 311 \\
$\quad$ Hired & 398 & 446 & 387 & 429 & 415 \\
Land preparation cost & 7519 & - & - & - & 1880 \\
(Tk./ha) & & & & & \\
Seedling/Cutting (No./ha) & 29218 & - & - & - & 7304 \\
Manures (kg/ha) & 1792 & 1422 & 1653 & 1319 & 1546 \\
Fertilizers (kg/ha)* & & & & & \\
$\quad$ Urea & 1315 & 2046 & 1730 & 1748 & 1710 \\
$\quad$ TSP & 736 & 1381 & 1298 & 1363 & 1194 \\
$\quad$ MoP & 614 & 441 & 536 & 778 & 592 \\
$\quad$ Zipsum & 480 & 458 & 296 & 579 & 453 \\
$\quad$ Zinc sulphate & 11 & 67 & 36 & 19 & 33 \\
Boron & 1 & 3 & - & 2 & 2 \\
Insecticides (Tk./ha) & 59498 & 54192 & 51510 & 55601 & 55200 \\
Irrigation (Tk./ha) & 29754 & 18612 & 22181 & 19668 & 22554 \\
\hline
\end{tabular}

*Recommended doses of fertilizers (Urea 1302kg/ha, TSP $1000 \mathrm{~kg} / \mathrm{ha}$ and MoP 400 $\mathrm{kg} / \mathrm{ha})$

\section{Cost and return from rose cultivation}

All variable costs incurred for human labour, land preparation, seedling, organic manure, fertilizers, insecticides, and irrigation were considered for calculating the cost of rose cultivation. The cost of land use was calculated on the basis of lease value of land. The average costs of rose cultivation were Tk. 3,87, 569, and Tk. 2,75,214 per hectare on full cost and variable cost basis, respectively. The major share of total cost was incurred for human labour (30\%) followed by land use (23\%), fertilizer (17\%), and irrigation (Table 4). In the first year garden, the cost of rose cultivation was found higher than the second, third and fourth year gardens due to the initial cost of establishing the garden. Comparative costs scenarios revealed that the cost of rose cultivation was much higher than that of different comparative cropping patterns. Rose cultivation cost was 36\%, 79\% and $82 \%$ higher compared to potato+jute, lentil+til and mustard+mungbean cropping patterns respectively (Table 6). 
Table 4. Cost and return of rose cultivation in the study area.

\begin{tabular}{|c|c|c|c|c|c|}
\hline \multirow{3}{*}{ Items } & \multirow{2}{*}{\multicolumn{5}{|c|}{ Cost of cultivation }} \\
\hline & & & & & \\
\hline & Ist year & 2nd year & $3^{\text {rd }}$ year & $4^{\text {th }}$ year & All \\
\hline A. Variable costs & $440854(80)$ & 225252(66) & 209762(65) & 224987(66) & 275214(69) \\
\hline Land preparation & 7519 (1) & - & - & - & $1880(1)$ \\
\hline Hired labour & 48012 (8) & $53531(16)$ & 46697(15) & 51543(15) & 49945(14) \\
\hline Seedling/cutting & 208643 (38) & - & - & - & $52160(12)$ \\
\hline Organic manure & $1289(0.23)$ & $953(0.28)$ & $1170(0.37)$ & $1010(0.29)$ & $1105(0.28)$ \\
\hline Chemical fertilizers & $53480(10)$ & $81277(24)$ & 72664(22) & $80497(24)$ & 71979(18) \\
\hline Urea & 15781 & 24558 & 20768 & 20985 & 20523 \\
\hline TSP & 18419 & 34530 & 32453 & 34083 & 29871 \\
\hline MoP & 15071 & 11062 & 13909 & 19786 & 14957 \\
\hline Zipsum & 2743 & 2538 & 1684 & 3270 & 2558 \\
\hline Zinc Sulphate & 1303 & 8063 & 3848 & 2128 & 3835 \\
\hline Boron & 161 & 523 & - & 241 & 231 \\
\hline Insecticides & $59498(11)$ & 54192(16) & $51510(16)$ & $55601(16)$ & $55200(14)$ \\
\hline Irrigation & $29754(5)$ & $18612(5)$ & 22181(7) & 19668(6) & $22554(5)$ \\
\hline $\begin{array}{l}\text { Interest on } \\
\text { operating capital }\end{array}$ & 32655 (6) & $16685(5)$ & $15537(5)$ & $16665(5)$ & 20385(5) \\
\hline B. Fixed cost & $111830(20)$ & 113274(34) & 111247(35) & 113071(34) & 112355(31) \\
\hline Family labour & 36982 (6) & $38426(12)$ & 36399(11) & 38223(11) & $37507(10)$ \\
\hline Land use & $74848(14)$ & $74848(22)$ & $74848(24)$ & 74848(23) & $74848(21)$ \\
\hline C. Total cost $(A+B)$ & $\begin{array}{c}552684 \\
(100)\end{array}$ & 338527(100) & $314772(100)$ & 338059(100) & 387569(100) \\
\hline Yield (Flowers/ha) & 303373 & 673028 & 680785 & 503244 & 540107 \\
\hline Price (Tk/flower) & 1.34 & 1.17 & 1.06 & 1.13 & 1.17 \\
\hline D. Gross return & 406520 & 787443 & 721632 & 568666 & 621065 \\
\hline Gross margin & -34334 & 562191 & 511870 & 343679 & 345852 \\
\hline Net return & -146164 & 448916 & 406860 & 230607 & 233496 \\
\hline \multicolumn{6}{|l|}{ E. Benefit cost ratio } \\
\hline Full cost basis & 0.74 & 2.33 & 2.29 & 1.68 & 1.63 \\
\hline Variable cost basis & 0.92 & 3.50 & 3.44 & 2.52 & 2.29 \\
\hline
\end{tabular}

Figures within the parentheses indicates percentage of total cost

The average yield of rose was 5,40,107 flowers per hectare (Table 4). The gross margin and net return of rose cultivation were Tk. 3,45,852 and Tk. 2,30,607 per hectare. The gross margin and net return were found negative in the first year garden due to higher initial cost of cultivation. The gross margin and net return were found highest in the second and third year garden than the first 
year and fourth year garden. The net return of rose cultivation was 38\%, 86\% and 81\% higher than its competing cropping patterns (Table 6).The benefit cost ratio was 1.63 and 2.04 on full cost and variable cost basis, respectively.

Table 5. Costs and returns of different competitive crops and cropping patterns of rose.

\begin{tabular}{|c|c|c|c|c|c|c|c|c|c|}
\hline Parameters & Potato & Jute & $\begin{array}{l}\text { Potato } \\
\text { +Jute }\end{array}$ & Lentil & Til & $\begin{array}{c}\text { Lentil } \\
+ \text { Til }\end{array}$ & Mustard & $\begin{array}{c}\text { Mung- } \\
\text { bean }\end{array}$ & $\begin{array}{l}\text { Mustard+ } \\
\text { Mungbean }\end{array}$ \\
\hline A. Variable cost & 164135 & 20124 & 184259 & 18846 & 23220 & 42066 & 14582 & 20194 & 37276 \\
\hline Hired labour & 21393 & 12000 & 33393 & 6630 & 7620 & 14250 & 4969 & 4911 & 9880 \\
\hline Land preparation & 5420 & 1497 & 6917 & 3225 & 3170 & 6395 & 2915 & 2825 & 5740 \\
\hline Seed & 69277 & 480 & 69757 & 1050 & 620 & 1670 & 552 & 650 & 1202 \\
\hline Manures & 3692 & 650 & 4342 & 830 & 650 & 1480 & 762 & 820 & 1582 \\
\hline Fertilizers & 43966 & 2500 & 46466 & 4576 & 7975 & 12551 & 3700 & 8315 & 14515 \\
\hline Pesticides & 10148 & - & 10148 & 820 & 1050 & 1870 & 88 & 350 & 438 \\
\hline Irrigation & 4663 & 2245 & 6908 & 1345 & 1220 & 2565 & 1291 & 1560 & 2851 \\
\hline $\begin{array}{l}\text { Interest on } \\
\text { operating capital }\end{array}$ & 5575 & 753 & 6327 & 370 & 915 & 1285 & 305 & 763 & 1068 \\
\hline B. Fixed cost & 46494 & 17132 & 43626 & 20316 & 18430 & 38746 & 17030 & 17132 & 34162 \\
\hline Family labour & 20000 & - & 20000 & 3000 & 2500 & 5500 & 2900 & 3500 & 6400 \\
\hline Land use & 26494 & 17132 & 43626 & 17316 & 15930 & 33246 & 14130 & 13632 & 27762 \\
\hline $\begin{array}{l}\text { C. Total cost } \\
(\mathrm{A}+\mathrm{B})\end{array}$ & 210629 & 37256 & 247885 & 39162 & 41650 & 80812 & 34112 & 37326 & 71438 \\
\hline Yield (kg/ha) & 26139 & 1400 & - & 1200 & 1494.48 & - & 979 & 1050 & - \\
\hline Price (Tk/kg) & 12.79 & 40.55 & - & 5142 & 35.00 & - & 53.44 & 60.35 & - \\
\hline D. Gross return & 335138 & 56770 & 391908 & 61692 & 52307 & 113999 & 52327 & 63367 & 115694 \\
\hline Gross margin & 171003 & 36646 & 187649 & 42846 & 29087 & 71933 & 35245 & 43173 & 78418 \\
\hline Net return & 124509 & 19514 & 144023 & 22530 & 10657 & 33187 & 18215 & 26041 & 44256 \\
\hline \multicolumn{10}{|c|}{ E. Benefit cost ratio } \\
\hline Full cost basis & 1.59 & 1.52 & 1.58 & 1.58 & 1.25 & 1.41 & 1.53 & 1.70 & 1.61 \\
\hline $\begin{array}{l}\text { Variable cost } \\
\text { basis }\end{array}$ & 2.04 & 2.82 & 2.13 & 3.27 & 2.25 & 2.71 & 3.59 & 3.14 & 3.10 \\
\hline
\end{tabular}

\section{Factors affecting rose yield}

In order to determine the contribution of inputs like human labour, land preparation, seedling, manure, urea, TSP, MoP, insecticide, and irrigation for rose production, Cobb- Douglas production function was used. The estimated values of co-efficient and related statistics of Cobb- Douglas production function are presented in Table 7 . The model reveals that the co-efficients of human labour, land preparation cost, seedling, $\mathrm{MoP}$ and irrigation were positively significant at $1 \%$ level indicate that $1 \%$ increase in the use of these inputs, keeping other factors remaining constant would increase the yield of rose by 
$0.001 \%, 0.016 \%, 0.043 \%, 0.051$ and $0.024 \%$ respectively. The co-efficient of urea and TSP were positively significant at $5 \%$ level indicated that $5 \%$ increase in the use of these inputs, keeping other factors remaining constant would increase the yield of rose by $0.051 \%$ and $0.052 \%$ respectively.

Table 6. Relative economic performance of rose cultivation with other competitive crops and cropping patterns.

\begin{tabular}{|c|c|c|c|c|c|c|c|}
\hline Parameters & Rose & $\begin{array}{l}\text { Potato } \\
\text { +Jute }\end{array}$ & $\begin{array}{c}\text { \% higher } \\
\text { than } \\
\text { Potato+Jute }\end{array}$ & $\begin{array}{c}\text { Lentil } \\
+ \text { Til }\end{array}$ & $\begin{array}{c}\% \\
\text { higher } \\
\text { than } \\
\text { lentil+T } \\
\text { il }\end{array}$ & $\begin{array}{c}\text { Mustard } \\
+ \\
\text { Mungbe } \\
\text { an }\end{array}$ & $\begin{array}{l}\text { \% higher } \\
\text { than } \\
\text { mustard+ } \\
\text { Mungbean }\end{array}$ \\
\hline A. Gross return & 621065 & 391908 & 37 & 113999 & 81 & 115690 & 81 \\
\hline B. Variable cost & 275214 & 184259 & 33 & 42066 & 84 & 37276 & 86 \\
\hline C. Total cost & 387569 & 247885 & 36 & 80812 & 79 & 71438 & 82 \\
\hline $\begin{array}{l}\text { D. Gross margin (A- } \\
\text { B) }\end{array}$ & 345852 & 187649 & 46 & 71933 & 79 & 78418 & 77 \\
\hline E. Net return (A-C) & 230607 & 144023 & 38 & 33187 & 86 & 44256 & 81 \\
\hline \multicolumn{8}{|l|}{ F. Benefit cost ratio } \\
\hline Full cost basis & 1.63 & 1.58 & - & 1.41 & - & 1.61 & - \\
\hline Variable cost basis & 2.04 & 2.13 & - & 2.71 & - & 3.10 & - \\
\hline
\end{tabular}

Table 7. Estimated coefficients and their related statistics of production function for rose.

\begin{tabular}{lcc}
\hline \multicolumn{1}{c}{ Explanatory Variables } & Co-efficient & t-value \\
\hline Intercept & $13.523^{* * *}$ & 3.92 \\
Human labor $\left(\mathrm{X}_{1}\right)$ & $0.001^{* * *}$ & 4.08 \\
Land preparation $\left(\mathrm{X}_{2}\right)$ & $0.016^{* * *}$ & 3.25 \\
Seedling/cutting $\left(\mathrm{X}_{3}\right)$ & $0.043^{* * *}$ & 2.62 \\
Manure $\left(\mathrm{X}_{4}\right)$ & $0.452 \mathrm{~ns}$ & 1.02 \\
Urea $\left(\mathrm{X}_{5}\right)$ & $0.051^{* * *}$ & 2.02 \\
TSP $\left(\mathrm{X}_{6}\right)$ & $0.052^{* *}$ & 2.54 \\
MoP $\left(\mathrm{X}_{7}\right)$ & $0.051^{* * *}$ & 2.63 \\
Irrigation $\left(\mathrm{X}_{8}\right)$ & $0.024^{* * *}$ & 3.79 \\
$\mathrm{R}^{2}$ & 0.56 & \\
F value & $5.79^{* * *}$ & \\
\hline
\end{tabular}

Note: $* * *$ and $* *$ indicate significant at $1 \%$ and $5 \%$ level respectively

The value of coefficient of determination $\left(\mathrm{R}^{2}\right)$ was 0.56 , which indicated that around $56 \%$ of the variation in yield was explained by the independent variables 
included in the model. The F-value was found 5.79 which were significant at $1 \%$ level implying that the variation of yield mainly depends on the explanatory variables included in the model.

Table 8. Constraints to rose cultivation in the study area.

\begin{tabular}{lc}
\multicolumn{1}{c|}{ Constraints } & \% of respondent farmers \\
\hline 1. Lack of technical knowledge & 40 \\
2. Non-availability of HYV seedling/cutting & 30 \\
3. Lack of transport facility & 60 \\
4. Disease and insects infestation & 45 \\
\hline
\end{tabular}

\section{Constraints to rose cultivation}

Although rose cultivation was observed to be a profitable crop, there are several constraints to its higher production. The constraints are shown in Table 8. It was found that $60 \%$ farmers reported that lack of transport facility ranked first constraint of rose cultivation. Others major constraints to rose cultivation were disease and insect's infestation (45\%), lack of technical knowledge (40\%), and non-availability of HYV seedlings (30\%).

\section{Conclusion}

The cultivation of rose was highly profitable at farm level because of its higher demand compared to its production. Human labour, land preparation, seedling, urea, TSP, MoP and irrigation had positive and significant effect on the yield of rose in the study areas. Among the competing crops like potato+jute, lentil+til and mustard+mungbean, respectively, the highest profit was obtained from rose. Lack of technical knowledge, high yielding varieties, infestation of disease and insects were major constraints for rose cultivation.

\section{Recommendations}

Based on the findings of the study, the following recommendations put forward for the improvement of rose cultivation at farm level.

- Farmers' training should be conducted by the BARI scientists to develop technical knowledge about improved cultivation practices of rose.

- High yielding varieties rose seedling/cutting should be made locally available to the farmers at proper time. For this reason, government should encourage researcher and private seed companies for producing HYV seedling/cutting of rose. 
- More intensive research should be undertaken by BARI scientists to develop disease and insect-pest resistant HYV varieties of rose in the near future.

\section{References}

Aditya, D. K. 1992. Floriculture in national economy. Proceedings of the $6^{\text {th }}$ National Horticultural Conference and Symposium. BSHS, P. 30-35.

BBS, 2008. Yearbook of Agricultural Statistics of Bangladesh, Bangladesh Bureau of Statistics, Ministry of Planning, Government of the Peoples Republic of Bangladesh, Dhaka.

Dadlani, N. K. 2003. Global Positioning of Bangladesh Floriculture. A Paper presented on a Seminar held on $6^{\text {th }}$ November, 2003, BARC, Farmgate, Dhaka. 